\title{
Alcohol- and Gasohol-Fuels: A Comparative Chamber Study of Photochemical Ozone Formation
}

\author{
Pedro Afonso de P. Pereira*, Leilane Maria B. Santos, Eliane Teixeira Sousa and \\ Jailson B. de Andrade
}

\author{
Instituto de Química, Universidade Federal da Bahia, Campus Universitário de Ondina, \\ 40170-290 Salvador - BA, Brazil
}

\begin{abstract}
Compostos orgânicos voláteis (COV) tem papel significativo no processo de formação do smog fotoquímico. Os fotooxidantes são formados na atmosfera quando os COV reagem com óxidos de nitrogênio em presença da luz solar e radicais $\mathrm{OH}$. Em áreas urbanas, veículos são uma importante fonte de COV e $\mathrm{NO}_{x}$ para a atmosfera, tanto pela queima quanto por evaporação de combustíveis. Neste trabalho são comparados dois tipos de combustível atualmente usados no Brasil - etanol hidratado (95\% v/v) e gasool (uma mistura de $22-24 \%$ de etanol anidro em gasolina) - em termos de precursores na formação de ozônio na atmosfera de cidades urbanas. Os experimentos foram feitos durante a primavera e verão de 2001/2002 e, em cada um, foram preenchidas duas bolsas de Teflon com cada um dos combustíveis, respectivamente, e altas razões iniciais [COV]/[NO], sendo a seguir as mesmas expostas à luz solar. Tanto a formação de ozônio quanto os perfis de concentração de NOx foram medidos diretamente com o uso de analisadores contínuos de ozônio e $\mathrm{NO} / \mathrm{NO}_{2} / \mathrm{NOx}$, respectivamente Os resultados mostraram que para os mesmos volumes iniciais de combustível em cada bolsa, as concentrações máximas de ozônio eram em média $28 \%$ maiores para o álcool do que para o gasool. Além disso, o processo de formação do ozônio iniciava-se antes para o gasool mas, uma vez iniciado em ambos os combustíveis, a taxa de formação tendia a ser duas vezes maior para o álcool, em comparação ao gasool. Tais observações indicam a necessidade de estudos mais detalhados, a respeito do papel das emissões derivadas de evaporação e combustível não queimado, nos processos de formação de oxidantes fotoquímicos na atmosfera, com atenção especial aos aspectos cinéticos. Isto é particularmente importante para o caso do Brasil, considerando-se a contribuição substancial dessas emissões para o inventário de hidrocarbonetos (HC) e COV, provenientes de fontes móveis em grandes cidades, e uma possível retomada do Programa Brasileiro de Biocombustíveis, a qual levaria a um aumento nas concentrações atmosféricas de etanol.
\end{abstract}

Volatile organic compounds (VOC) play a significative role on the process of formation of photochemical smog. Photooxidants are formed in the atmosphere when VOC react with nitrogen oxides (NOx), in the presence of sunlight and $\mathrm{OH}$ radicals. In urban areas, vehicle fuels constitute an important source of VOC and NOx emissions to the atmosphere, either by burning or evaporative losses. This work is concerned with a comparative study of two types of light-duty vehicular fuels presently used in Brazil - namely gasohol (a mixture 22-24\% of anhydrous ethanol in gasoline) and hydrated ethanol $(95 \% \mathrm{v} / \mathrm{v})$ - as potential precursors for ozone formation in the atmosphere of urban cities. The experiments were conducted during the spring and summer of 2001/2002. In each one, two Teflon chambers were filled, respectively, with each fuel, at high initial [VOC] to [NO] ratios and exposed to the sunlight. Ozone formation, as well as NOx concentration profiles were measured directly using ozone and $\mathrm{NO} / \mathrm{NO}_{2} / \mathrm{NOx}$ continuous analyzers. The results showed that, for the same initial volumes of the two fuels into the bags, the ozone peak concentrations are in average $28 \%$ higher for alcohol than for gasohol. In addition, the ozone formation process showed a tendency to start earlier for gasohol but, once started, the formation rate was two times faster for alcohol than for gasohol. These observations indicate a need for more detailed studies, regarding the role of unburned fuel emissions and evaporative losses of alcohol and gasohol on the formation process of atmospheric photochemical oxidants in urban sites, with special attention to kinetics aspects. This conclusion is particularly important in the case of Brazil, considering the substantial contribution of that emissions on the total hydrocarbons (HC) and VOC inventories from mobile sources and a possible resume of the Brazilian Biofuels Program, which would increase the atmospheric concentrations of ethanol.

Keywords: atmospheric ozone precursors, vehicular fuels, smog chamber experiments

\footnotetext{
*e-mail: pedroapp@ufba.br
} 


\section{Introduction}

Volatile organic compounds (VOC) have a significative effect on the photochemical smog formation. Photooxidants are formed in the atmosphere when organic reactive compounds interact with nitrogen oxides $\left(\mathrm{NO}_{\mathrm{x}}\right)$, under sunlight and in the presence of ${ }^{\circ} \mathrm{OH}$ radicals.

Amongst the photooxidants formed in the troposphere, ozone is one of the most important, as it plays a central role in the chemistry of this atmosphere layer. ${ }^{1}$ Besides its toxicity to humans and plants, it has a high reactivity and oxidant behavior and can absorb ultraviolet and infrared radiations, which make it a contributor to the greenhouse effect.

Since ozone is formed, as a secondary pollutant, from reactions between nitrogen oxides and VOC, the control of its concentration in urban atmospheres depends ultimately on the emission control of those precursors. In urban areas, the vehicular fleet is an important source of $\mathrm{NO}_{x}$ and also of VOC, not only due to burned/unburned fuel but also due to evaporative losses.

According to inventories of emitted hydrocarbons (HC) during 2002 in São Paulo, the biggest city of Brazil and South America, a significant fraction of them comes from evaporative emissions, which are estimated to contribute with about $43 \%$ of the total emitted $\mathrm{HC}$ from mobile sources, while operations of fuel transfer are estimated to contribute with about $3 \%$ of the total. ${ }^{2,3}$

Also, studies carried out in Rio de Janeiro, measuring the $\mathrm{HC} / \mathrm{CO}$ concentration ratios at several locations, established that $\mathrm{HC}$ emissions in a downtown site were very similar to those from parking garages, where evaporative plus off-cycle exhaust emissions are of the same order of magnitude than those of hot-stabilized exhaust emissions. ${ }^{4}$ Thus, the role of unburned and evaporative emissions tends to be of paramount importance to the formation of photochemical ozone in big cities.

Trends in the regional use of biomass-derived fuels, such as alcohols, biodiesel and agricultural residues - as a proposed control initiative against elevated carbon monoxide levels in urban areas - have expanded to a global scale. The general interest in biofuels obviously results from economic considerations but, more recently, increasing attention has also been due to the role that their combustion products may have on the question of global warming and on reducing the smog formation, as well as an alternative to substitute methyl tert-butyl ether as a gasoline additive, in view of its potential threat to water quality, mainly as result of leaks in gasoline storage tanks.

The vehicular fleet in Brazil is quite unique in the world, as its light-duty vehicles, running in the largest cities, are fueled with a blend 22-24\% (v/v) of anhydrous ethanol in gasoline - namely gasohol - or with pure hydrated ethanol. In the beginning of 90's, about $41 \%$ of the light-vehicles running in Salvador - the capital of Bahia, a big state in the northeastern region of Brazil were fueled with pure hydrated ethanol, and that proportion was probably very similar in many other big Brazilian cities. ${ }^{5}$ More recent statistics ${ }^{6}$ state that, during 2002, about 22 billions $\mathrm{L}$ of regular gasoline and 3.6 billions $\mathrm{L}$ of hydrated ethanol were sold in Brazil. If one considers the fraction of ethanol in gasohol, ethanol participated with 33 to $34.7 \%$ in total sales, while as exclusive fuel its participation fell to $14 \%$, although a possible resume of the Brazilian Biofuels Program is not discarded. Meanwhile, in the middle of the 90's years, the atmospheric levels of ethanol measured in Salvador were in the range of 12.5 to 154.9 ppb. $^{\text {? }}$

The evidences that the use of ethanol, as fuel or fuel additive, leads to an increase in the atmospheric levels of acetaldehyde and in the acetaldehyde-to-formaldehyde ratios are well established in many works. ${ }^{8-12}$ The weighted aldehyde emission factors, for the ethanol vehicles operated under the urban driving cycle without catalytic converter, were in the range of 19 to $46 \mathrm{mg} / \mathrm{km}$ for formaldehyde and 143 to $246 \mathrm{mg} / \mathrm{km}$ for acetaldehyde. Immediately after installation of the converters, substantial reductions were observed, although the acetaldehyde emissions remain higher than formaldehyde. ${ }^{13}$

The reactions involving ethanol, which lead to ozone formation and carbonyl compounds, are briefly described bellow:

$$
\begin{aligned}
& \mathrm{CH}_{3} \mathrm{CH}_{2} \mathrm{OH}+{ }^{\cdot} \mathrm{OH} \rightarrow \mathrm{CH}_{3} \cdot \mathrm{CHOH}+\mathrm{H}_{2} \mathrm{O} \\
& \mathrm{CH}_{3}{ }^{\circ} \mathrm{CHOH}+\mathrm{O}_{2} \rightarrow \mathrm{CH}_{3} \mathrm{CHO}+{ }^{\circ} \mathrm{OOH} \\
& { }^{\circ} \mathrm{OH}+\mathrm{NO} \rightarrow \mathrm{NO}_{2}+{ }^{\circ} \mathrm{OH} \\
& \mathrm{NO}_{2}+\mathrm{h} v \rightarrow \mathrm{NO}+\mathrm{O} \\
& \mathrm{O}+\mathrm{O}_{2}+\mathrm{M} \rightarrow \mathrm{O}_{3}+\mathrm{M}
\end{aligned}
$$

where reaction (1) predominates (ca. 90\%) over the hydrogen abstraction from the primary carbon and from the hydroxyl.

Several experiments have been done in environmental chambers by different authors, in order to determine the individual contributions of several VOC on the ozone formation. ${ }^{14-18}$ Most part of these experiments were performed under conditions that simulated high or low $\left[\mathrm{NO}_{\mathrm{x}}\right]-$ to $-[\mathrm{VOC}]$ ratios, either by captive air exposure or by using synthetic standard mixtures that simulated photochemical precursors. On the other way, modeling studies were used to predict ozone concentrations in urban atmospheres or reactive mixtures..$^{8,19-23}$ 
Nevertheless, individual VOC can differ substantially in their effects on ozone formation, not only because they react in the atmosphere according to different velocities, but also due to the way their products can influence on the ozone concentrations. ${ }^{24}$

Besides, it must be taken into account that VOC are not present in an individual form in the atmosphere. Instead, they are usually present as a complex mixture and, not rarely, reactivity of each one and its potential as an ozoneforming will depend, amongst other factors, on the rest of the total composition. ${ }^{19}$

In this work, environmental chamber experiments were conducted simultaneously with typical commercially available Brazilian fuels - gasohol and hydrated ethanol exposed to variables ratios of [VOC] to [NO] and under sunlight irradiation. Results of ozone formation and reaction kinetics are compared for both types of fuel.

\section{Experimental}

The metropolitan area of Salvador is located on the Atlantic coast of Brazil at $13^{\circ} 01^{\prime} \mathrm{S}$ and $38^{\circ} 31^{\prime} \mathrm{W}$, with about 2.5 million inhabitants distributed over a $324 \mathrm{~km}^{2}$ area. It is a tropical city with yearly average maximum and minimum temperatures of $32{ }^{\circ} \mathrm{C}$ and $19{ }^{\circ} \mathrm{C}$, respectively.

Following the optimization of the experimental conditions, four sets of experiments were run, each one with the two samples (alcohol and gasohol), during the southern hemisphere's spring and summer of 2001/2002. Fuels (gasohol and hydrated ethanol, normal grade), were acquired at a local gas station and stored in amber glass bottles. For each run, equal volumes $(10 \mu \mathrm{L})$ of both fuels were injected, respectively, with glass micro syringes (Hamilton, Nevada), into two separated 250 L Teflon chambers (Roberts Andersen) initially covered with plastic black sheet. The chamber's material was appropriate for the experiments, as it is chemically inert, almost impermeable to gases and transmits up to $94 \%$ of incident light in the region of 290 to $450 \mathrm{~nm} .{ }^{25}$

During the fuel injection and afterwards, chambers were filled up with pure air (Thermo Environmental Instruments Inc. model 111 zero air supply), firstly passing through a glass bottle with water, in order to generate air humidities between 70 and $80 \%$, typical of the climate in Salvador. The humidity was checked with a thermo hygrometer (Minipa model MTH-1380). Before chambers reached their end volume, a NO gaseous standard mixture (33 to $40 \mathrm{ppm}$ in nitrogen) was injected, with a glass syringe, in order to have an initial NO concentration between circa of 300 to $700 \mathrm{ppb}$.

The chambers were then simultaneously uncovered and exposed to sunlight, for time periods ranging six hours and beginning in the morning. During exposure, reactions were continuously monitored for $\left[\mathrm{O}_{3}\right],[\mathrm{NO}]$ and $\left[\mathrm{NO}_{2}\right]$ (Thermo Environmental Instruments Inc. model 49 ozone analyzer and model $42 \mathrm{NO}_{x}$ analyzer, respectively). The $\mathrm{NO} / \mathrm{NO}_{2}$ analyzer was periodically calibrated with gaseous standard mixtures of $\mathrm{NO}$ and $\mathrm{NO}_{2}$, from which appropriate dilutions were made in air bags, while the ozone analyzer was calibrated with an ozone calibrator (Thermo Environmental model 49 PS).

\section{Results and Discussion}

The initial volume of each type of fuel, injected into the chambers $(10 \mu \mathrm{L})$ represented, for alcohol, an initial concentration of about $9 \mathrm{ppmC}$ (ppm of carbon), thus giving initial [VOC]/[NO] ratios ranging from 13.4 to 30.9. The calculations is somewhat more elaborated for gasohol, as it contains about $32 \%(\mathrm{~m} / \mathrm{m})$ of ethanol on its composition. ${ }^{26}$ If we consider an average molecular weight of 100 for the gasoline fraction, then the initial concentration was about $7 \mathrm{ppmC}$ in gasohol and $[\mathrm{VOC}] /[\mathrm{NO}]$ ratios ranged from 12.5 to 22.2 . Hence, in both cases, experiments were conducted with an excess of VOC and so, ozone formation was limited by NO concentrations.

While the amount of fuel remained fixed in all experiments, the initial NO concentration could vary, due to precision limitations in its injection system.

The experimental conditions of the reaction chambers, as well as initial $[\mathrm{NO}]$, maximum $\left[\mathrm{NO}_{2}\right]$ and ozone peak concentrations, read for each experiment, are summarized in Table 1.

In an absolute basis, fuel alcohol was observed to produce ozone peak concentrations greater than gasohol, this difference ranging from 24 to $36 \%$. This trend toward a great ozone production by alcohol, could be emphasized by the $\left[\mathrm{O}_{3}\right]_{\max } /[\mathrm{NO}]_{\text {init }}$ ratios, which were always greater for alcohol, although the experiment run on March 22 showed a smaller difference between alcohol and gasohol $(0.21$ and 0.20 ). Since for that run $\left[\mathrm{NO}_{2}\right]_{\max }$ values were considerably larger, this could be also reacting with oxygencontaining reaction products, such as aldehydes, to produce peroxyacyl nitrates, like PAN, and thus less ozone would be formed. The trends in the ozone formation also follow the $[\mathrm{VOC}]_{\text {init }} /[\mathrm{NO}]_{\text {init }}$, showing the important influence of this ratio on the maximum ozone concentrations found.

Typical concentration curves for ozone, for both fuels, are illustrated on Figure 1, plotted from experiment conducted on November 8 . The ozone peaks were reached during the afternoon, four to five hours after the beginning of the experiments. 
Table 1. Experimental conditions and main results for chamber exposures of fuel alcohol and gasohol

\begin{tabular}{|c|c|c|c|c|c|c|c|c|}
\hline Experiment & Beginning & End & $\begin{array}{c}{[\mathrm{NO}]_{\text {init }}} \\
(\mathrm{ppb})\end{array}$ & $\begin{array}{l}{\left[\mathrm{NO}_{2}\right]_{\max }} \\
(\mathrm{ppb})\end{array}$ & $\begin{array}{c}{\left[\mathrm{O}_{3}\right]_{\max }} \\
(\mathrm{ppb})\end{array}$ & Peak Hour & {$[\mathrm{VOC}]_{\text {init }} /[\mathrm{NO}]_{\text {init }}$} & {$\left[\mathrm{O}_{3}\right]_{\max } /[\mathrm{NO}]_{\text {init }}$} \\
\hline \multicolumn{9}{|l|}{ Nov/8/01 } \\
\hline alcohol & \multirow{3}{*}{ 9:00 } & \multirow{3}{*}{$14: 10$} & 366 & 258 & 167 & \multirow{3}{*}{$13: 00$} & 24.6 & 0.46 \\
\hline & & & & & & & & \\
\hline gasohol & & & 316 & 140 & 123 & & 22.2 & 0.39 \\
\hline \multirow{3}{*}{$\begin{array}{l}\text { Nov/13/01 } \\
\text { alcohol }\end{array}$} & \multirow{4}{*}{ 9:00 } & \multirow{4}{*}{$15: 40$} & & & & \multirow{4}{*}{$14: 20$} & & \\
\hline & & & 291 & 198 & 158 & & 30.9 & 0.54 \\
\hline & & & & & & & & \\
\hline gasohol & & & 322 & 212 & 127 & & 21.7 & 0.39 \\
\hline \multicolumn{9}{|l|}{ Mar/1/02 } \\
\hline alcohol & \multirow{3}{*}{$10: 10$} & \multirow{3}{*}{$17: 00$} & 466 & 352 & 134 & \multirow{3}{*}{$15: 20$} & 19.3 & 0.29 \\
\hline & & & & & & & & \\
\hline gasohol & & & 451 & 231 & 105 & & 15.5 & 0.23 \\
\hline \multirow{3}{*}{$\begin{array}{l}\text { Mar/22/02 } \\
\text { alcohol }\end{array}$} & \multirow{4}{*}{ 10:00 } & \multirow{4}{*}{$16: 10$} & & & & \multirow{4}{*}{$14: 20$} & & \\
\hline & & & 671 & 623 & 144 & & 13.4 & 0.21 \\
\hline & & & & & & & & \\
\hline gasohol & & & 561 & 441 & 115 & & 12.5 & 0.20 \\
\hline
\end{tabular}

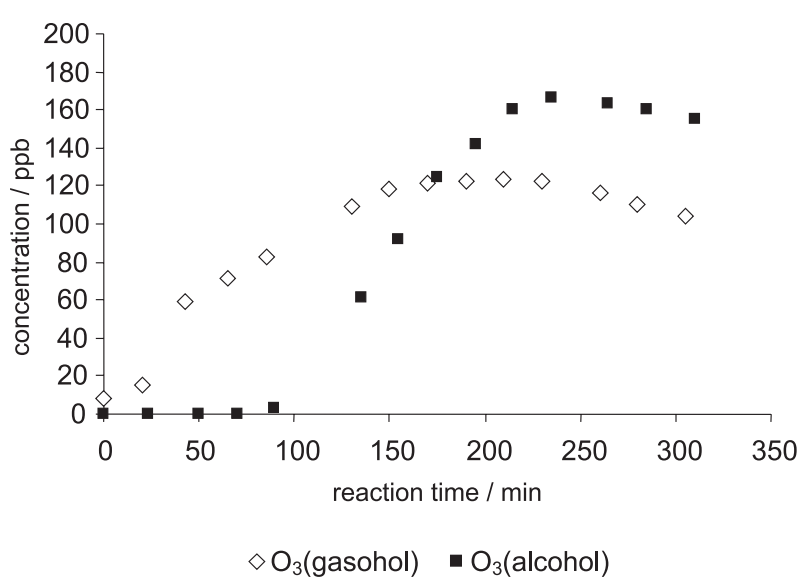

Figure 1. Typical ozone formation curves, obtained from exposures to sunlight of alcohol/NO- and gasohol/NO-mixtures.

The evolution of the ozone formation curves, however, did not present similar profiles for both types of fuel, as can be viewed on Figure 1. While the ozone concentration began to grow almost immediately with the exposure of gasohol to sunlight, for alcohol that growth was delayed by time periods ranging from 60 to 120 minutes. Nevertheless, as that raise started, the rate of the reaction was faster for alcohol. This was corroborated by the rate constants for the reactions of initial ozone formation, $\mathrm{k}_{\text {alcohol }}$ and $\mathrm{k}_{\text {gasohol }}$, calculated for all experiments in the slope region of the curves, which gave mean values of, respectively, $7.41 \times 10^{-16} \mathrm{~mol} \mathrm{~cm}^{-3} \mathrm{seg}^{-1}$ and $3.3 \times 10^{-16} \mathrm{~mol}$ $\mathrm{cm}^{-3} \mathrm{seg}^{-1}$, their ratios ranging from 1.8 to 3.3 .

The earliest beginning of ozone formation by gasohol, was predictable from the $[\mathrm{NO}]$ and $\left[\mathrm{NO}_{2}\right]$ curves for both fuels. Figures 2 and 3 show typical plots for the experiments run with gasohol and alcohol, respectively. It can be seen for gasohol that, as the NO concentration fell down quickly, $\mathrm{NO}_{2}$ concentration, also quickly, reached its maximum (Figure 2). For alcohol, on the other hand, the $\mathrm{NO}$ concentration decay and $\mathrm{NO}_{2}$ concentration raise were slower (Figure 3).

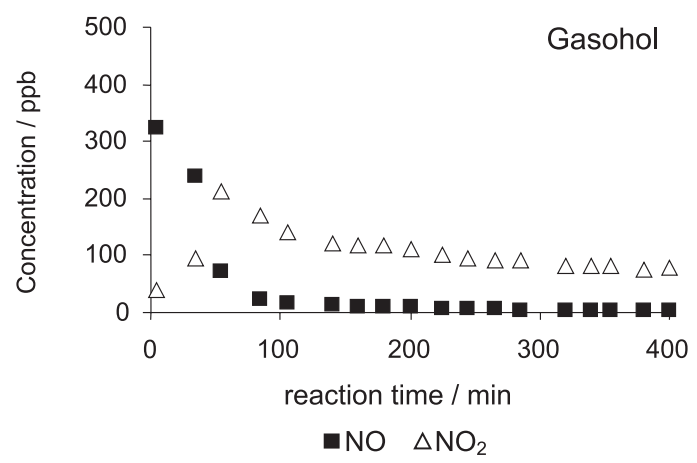

Figure 2. Typical curves of $[\mathrm{NO}]$ decay and $\left[\mathrm{NO}_{2}\right]$ raise for gasohol.

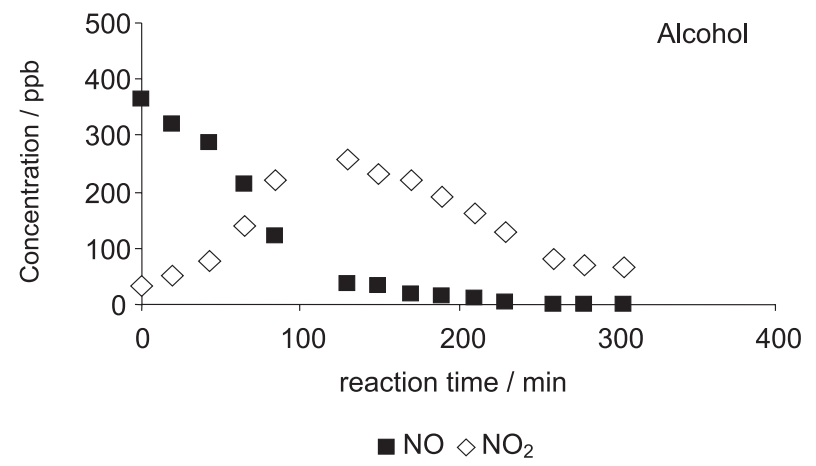

Figure 3. Typical curves of $[\mathrm{NO}]$ decay and $\left[\mathrm{NO}_{2}\right]$ raise for alcohol. 
The process by which VOC promote or inhibit ozone formation involves several complex factors. The ozone formation by VOC is previously followed by a series of reactions that lead to production of reactive radicals (e.g.ROO., . $\mathrm{OOH}$ ), which in turn may oxidize $\mathrm{NO}$ to $\mathrm{NO}_{2}$. Once formed, $\mathrm{NO}_{2}$ may decompose under photolysis and gives rise to atomic oxygen, which reacts with oxygen molecules according to the previously showed equations 4 and 5, and thus shifts the ozone photostationary state that predominates in a clean atmosphere towards higher ozone levels. ${ }^{15}$

On the other hand the hydrocarbons in excess, specially those containing unsaturated double bonds, may react with the ozone formed, according to the well known reaction ${ }^{27-29}$ which follows (6). In this case, VOC would be acting as ozone sinks.

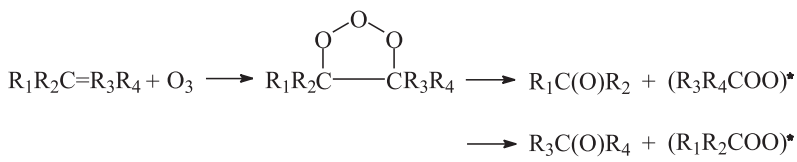

For both types of fuel - alcohol and gasohol - the initial step to the ozone formation process in the atmosphere is the ${ }^{\circ} \mathrm{OH}$ radical attack to the VOC molecule. With alcohol and saturated hydrocarbons, this is done via an hydrogen atom abstraction, forming the hydroxyalkyl and alkyl radicals respectively, due to its strong tendency to form stable water molecules. Unsaturated hydrocarbons, on the other way, tend to react via an ${ }^{\circ} \mathrm{OH}$ radical addition to the double bond, producing a $\beta$-hydroxyalkyl radical.

Brazilian fuel alcohol, which is basically hydrated

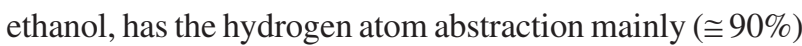
from its secondary carbon (see equation 1 ), for which the rate constant is $\mathrm{k}_{298}=3.2 \times 10^{-12} \mathrm{~cm}^{3}$ molecule $^{-1} \mathrm{seg}^{-1}$ and producing the $\alpha$-hydroxyalkyl radical. ${ }^{1}$ Gasoline in turn is a complex mixture of hydrocarbons - paraffins, isoparaffins, cycloparaffins, olefins, aromatics - which depends on factors such as the origin of the crude oil used for refining and refining conditions. In general, the hydrocarbon groups are chains of 4 to 12 carbon atoms. ${ }^{30}$ For these, the rate constants of reactions with ${ }^{\circ} \mathrm{OH}$ radicals are quite variable, but can range from values near that of ethanol to ten times higher. ${ }^{1,31}$ This could explain the faster initial decay of $[\mathrm{NO}]$ and the earliest beginning of ozone formation from gasohol.

We can also observe from Table 1 that, although the initial NO concentrations in alcohol experiments were only, in average, $7 \%$ greater than in gasohol experiments (up to $20 \%$ greater), the respective maximum $\mathrm{NO}_{2}$ concentrations that were reached were about $43 \%$ greater in alcohol experiments (up to $84 \%$ greater). A possible explanation is that, as the alkylperoxy radicals were formed, by reaction between oxygen, alkyl or $\beta$-hydroxyalkyl radicals from hydrocarbons, they partially tend to react with $\mathrm{NO}$, giving the stable alkylnitrate, according to equations 7 and 8 bellow:

$\mathrm{R} \cdot+\mathrm{O}_{2} \rightarrow \mathrm{ROO}$.

$\mathrm{ROO} \cdot+\mathrm{NO} \rightarrow \mathrm{RONO}_{2}$

Although ethanol may undergo the same reaction, only a small portion of it $(<2 \%)$ follows this route. Thus, for gasohol, an appreciable fraction of NO initially present would not be available to be oxidized to $\mathrm{NO}_{2}$ which, along with the possible ozone consumption by olefins, present in the excess of gasohol, could be responsible for the lower production rates and peak concentrations of ozone by this type of fuel.

\section{Conclusions}

In experiments conducted in spring and summer of 2001/ 2002, transparent Teflon chambers, containing air mixtures of NO and Brazilian commercial fuels alcohol and gasohol, were irradiated with sunlight and monitored for ozone formation. The volume of fuel that was put into the chamber remained constant $(10 \mu \mathrm{L})$ along all the experiments, while the $[\mathrm{VOC}] /[\mathrm{NO}]$ ratio ranged from 12.5 to 30.9 .

The results showed that, for equal volumes of the two types of fuel into the bags, both representing an excess of VOC over NO, the ozone peak concentrations are in average $28 \%$ higher for alcohol compared with gasohol, with values ranging, respectively, from 134 to $167 \mathrm{ppbv}$ for alcohol, and 105 to $127 \mathrm{ppbv}$ for gasohol. The exposure of chambers to sunlight lasted 6 hours in average and the maxima ocurred in the beginning of the afternoon.

In addition, the ozone formation process showed a tendency to start earlier for gasohol but, once it has started for both fuels, its concentration raised up two times faster for the alcohol fuel.

These observations indicate a need for more detailed studies, regarding the role of unburned fuel emissions and evaporative losses of alcohol and gasohol on the formation mechanisms of atmospheric photochemical oxidants in urban sites, with special attention to the reaction kinetics.

This conclusion is particularly emphasized in the case of Brazil, considering the substantial contribution of that emissions on the total $\mathrm{HC}$ and VOC inventories from mobile sources and a possible resume of the Brazilian Biofuels Program, which would increase the atmospheric concentrations of ethanol. 


\section{Acknowledgements}

The authors wish to thank to the Conselho Nacional de Desenvolvimento Científico e Tecnológico (CNPq) and the Fundação de Amparo a Pesquisa do Estado da Bahia (FAPESB). They also thank the valuable suggestions made by the referees.

\section{References}

1. Finlayson-Pitts B. J.; Pitts Jr., J. N.; Chemistry of the Upper and Lower Atmosphere; Academic Press: San Diego (CA), 2000.

2. CETESB Relatórios de Qualidade Ambiental no Estado de São Paulo, série relatórios 2002.

3. Andrade, M. de F.; Ynoue, R. Y.; Harley, R.; Paper 69561, $96^{\text {th }}$ Annual AWMA Meeting, San Diego, CA, 2003.

4. Grosjean, D.; Grosjean, E.; Rasmussen, R. A.; Moreira, L. F. R.; Moreira, A.; Paper 69182, $96^{\text {th }}$ Annual AWMA Meeting, San Diego, CA, 2003.

5. Pereira, P. A. de P.; de Andrade, J. B.; Quim. Nova 1998, 21, 744.

6. http://www.anp.gov.br/doc/dados_estatisticos/ Vendas_de_Combustiveis_m3.xls, accessed in November 2003.

7. Pereira, P. A. de P.; Santos, E. T. S.; Ferreira, T. de F.; de Andrade, J. B.; Talanta 1999, 49, 245.

8. Martins, E. M.; Correa, S. M.; Arbilla G.; Atmos. Environ. 2003, 37, 23.

9. Grosjean, D.; Miguel, A. H.; Tavares, T.; Atmos. Environ. 2002, 22, 1637.

10. de Andrade, M. V.; Pinheiro, H. L. C.; Pereira, P. A. de P.; de Andrade J. B.; Quim. Nova 2002, 25, 1117.

11. de Andrade, J. B.; Andrade, M. V.; Pinheiro, H. L. C.; J. Braz. Chem. Soc. 1998, 9, 219.

12. Tanner, R. L.; Miguel, A. H.; de Andrade, J. B.; Gaffney, J. S.; Streit, G. E.; Environ. Sci. Technol. 1988, 22, 1026.
13. Miguel, A. H.; de Andrade, J. B.; J. Braz. Chem. Soc. 1990, 1, 124.

14. Grosjean, E.; Grosjean, D.; J. Braz. Chem. Soc. 1998, 9, 131.

15. Carter, W. P. L.; Pierce J. A.; Luo, D.; Malkina, I. L.; Atmos. Environ. 1995, 29, 2499.

16. Kelly, N. A.; Chang, T. Y.; Atmos. Environ. 1999, 33, 2101.

17. Geiger, H.; Kleffmann, J.; Wiesen, P.; Atmos. Environ. 2002, 36, 1737.

18. Tsai, J. H.; Chiang, H. L.; Hsu, Y. C.; Weng, H. C.; Yang, C. Y.; Atmos. Environ. 2003, 37, 2485.

19. Bowman, F. M.; Seinfeld, J. H.; Atmos. Environ. 1994, 28, 3359.

20. Carter, W. P. L.; Atmos. Environ. 1995, 29, 2513.

21. Wang, L. H.; Milford, J. B.; Carter, W. P. L.; Atmos. Environ. 2000, 34, 4349.

22. Martien, P. T.; Harley, R. A.; Milford, J. B.; Russel, A. G.; Environ. Sci. Technol. 2003, 37, 1598.

23. Geiger, H; Becker, K. H.; Wiesen, P.; J. Air Waste Man. Ass. 2003, 53, 425.

24. Carter, W. P. L.; J. Air Waste Man. Ass. 1994, 44, 881.

25. Nunes, F. M. N.; PhD Thesis, Universidade Federal da Bahia, Brazil, 1999.

26. de Andrade, J. B.; Pereira, P. A. de P.; Oliveira, C. da S. L.; Am. Environ. Lab. 1997, 8, 10.

27. Atkinson, R.; Carter, W. P. L.; Chem. Rev. 1984, 84, 437.

28. Carter, W. P. L.; Atmos. Environ. 1990, 24A, 481.

29. Grosjean, E.; de Andrade, J. B.; Grosjean, D.; Environ. Sci. Technol. 1996, 30, 975.

30. http://www.ccohs.ca/oshanswers/chemicals/chem_profiles/ gasoline/basic_gas.html, accessed in September 2003.

31. Atkinson, R.; J. Phys. Chem. Ref. Data 1997, 26, 215.

Received: November 28, 2003 Published on the web: August 9, 2004 